\title{
Responding to the crisis: food co-operatives and the solidarity economy in Greece
}

\author{
Theodoros Rakopoulos \\ The Human Economy Project, Faculty of Humanities, University of Pretoria, Private Bag x20, Hatfield, Pretoria, 0028, South Africa \\ trakopoulos@gmail.com
}

This article discusses a case of popular social response to imposed austerity and recession in Greece. It focuses on the antimiddleman movement in an Athens suburb. It also addresses the broader picture of the current Greek crisis, explaining how participants in this grassroots response extend their activity beyond food distribution, beginning to imagine modes of economic conduct and interaction different from those currently dominant in Greece. I explore their efforts to turn the food market they have established in Athens into a formal co-operative which links consumers in their neighbourhood directly to selected farmers through bonds of solidarity, and to work with others to create a network of similar co-operatives which will span the whole country. I argue that their endeavours strongly resemble the co-operativism and practical socialism advocated by important social theorists such as Mauss and Polanyi, and suggest that it may be important for the young activists in Athens to learn more about their ideas.

Keywords: Greek crisis, sovereign debt crisis, anti-middleman movements, food co-operatives, horizontal co-operative networks, Marcel Mauss, Karl Polanyi

This article discusses a case of popular social response to imposed austerity and recession in Greece. ' It focuses on the anti-middleman movement in an Athens suburb. It also addresses the broader picture of the current Greek crisis, explaining how participants in this grassroots response extend the scope of their activity beyond food distribution and begin to imagine modes of economic conduct and interaction radically different from those which are currently dominant in Greece. My attempt to understand the economic activities in which members of this anti-middleman movement in Athens engage has opened a window onto their ambitious political project, which aims to restructure Greek society as a whole.

The closer one gets to their mundane, everyday activity of distributing food to people in a part of Athens that has been particularly hard hit by the current imposition of austerity measures, the more one appreciates the all-encompassing character of their political worldview. Ethnographic research into particular people's practical reactions to crisis can, as in the instance I discuss below, provide a perspective on political debates and struggles at the macro or societal level. Economists may tell us that the current Greek crisis is a macro-economic phenomenon, amenable to resolution at the macrolevel only. But the way the subjects of my research integrate their practical responses to excessive food prices and their ambitious vision of how Greece could escape this and future crises suggests the importance of other approaches to the issues at stake. My field research among the people associated with the anti-middleman movement in Athens stimulates me to pose a straightforward question at the end of this article. Why does the media concentrate on the immediate, easily observable aspects of the activities of activist movements (when, that is, they condescend to notice these activities at all), and provide little or no information on their larger politi- cal ambitions?

\section{The Greek crisis}

The fact that the Greek economy was heavily in debt was brought to public attention early in 2010, and then defined by economists as a 'sovereign debt crisis', implying that the Greek state and (of course) its citizens had to take responsibility for paying off the debt that had been incurred. In terms of this definition of the problem, the Greek government was obliged to appeal for emergency loans in order to stave off national bankruptcy. The loans were intended to provide a breathing space during which the government would be able to put measures in place to cut expenditure and make savings. The savings were to be the means by which the government could repay Greece's international creditors. The loans, which came from a so-called 'troika' of the European Central Bank, the International Monetary Fund, and the European Union, were made conditional on the introduction of structural adjustment measures by the Greek government. The first loan, made within a few months of the announcement of the crisis, was for IIO billion Euros; the second, made in 201 I, was for 130 billion Euros. Since these huge sums require future repayment, many Greeks see the loans as deepening rather than alleviating the sovereign debt crisis. Few citizens can imagine how it will ever be possible to repay the loans, let alone the prior debt for which they are intended to provide cover.

The medicine rapidly proved worse than the illness. The structural adjustment measures demanded by the troika of emergency lenders have caused Greece's Gross Domestic Product (GDP) to shrink by a quarter since their imposition in 2010. This marks the fastest economic decline any European country has undergone since the Second World War. Greece is now referred to derogatorily in mainstream media as a

I. I would like to acknowledge the help offered by John Sharp and Ted Powers, and thank the two anonymous reviewers of Anthropology Southern Africa for their feedback. 
'grounded PIIG'. ${ }^{2}$ A large number of businesses have gone bankrupt and been shut down. According to official figures, unemployment stood at $28 \%$ of the total labour force in mid2013 , with youth unemployment at $68 \%$ and rising. Public spending on health and education has been slashed, and the majority of Greeks find it impossible to access even basic health services (Stuckler and Basu 2013). Meanwhile, the price of consumer goods has continued to rise from $2010 \mathrm{lev}$ els, and the purchasing power of all social classes - the middle class as well as the working class and the unemployed poor has been drastically eroded.

The imposed austerity measures have also added a political dimension to the debt crisis (Varoufakis 20I I). Since 2010 the Greek state has changed its executive administration four times, with several forms of political representation being tried. Successive governments have been constituted by farright and centre-left coalitions, as well as by specially selected technocrats. The Coalition of the Radical Left (SYRIZA) party significantly increased its share of the vote and its representation in parliament in the 2012 general election. At the same time, the neo-fascist Golden Dawn movement graduated from an insignificant extra-parliamentary militia to the fifth largest party in parliament. Current polls suggest that it may double its vote in the next election. The economic crisis has made the political situation extremely fluid, opening the door to many new forms of grassroots politics.

\section{The anti-middleman organisation}

In recent years there have been several spontaneous reactions to different aspects of the crisis (Herzfeld 20II, Theodossopoulos 2013). For instance when, to save money, the government shut down the National Broadcasting Service (ERT) by decree in June 20I3, thousands of Athenians staged an immediate sit-in in the ERT building. Numerous demonstrations - some turning into widespread social unrest and even riots - have taken place over the past three years. Some of these responses have, however, given rise to more enduring grassroots organisation. One example of this is the steps that have been taken by groups of people rendered homeless by the crisis to invade derelict or unoccupied buildings in Athens and other cities and turn them into 'squats'. Some of these squats have, in addition, been turned into informal social centres, providing voluntary services of various kinds to people who have become impoverished in surrounding areas. There are similarities here with social responses to crises caused by structural adjustment programmes elsewhere (Sitrin 2012).

My field research was located in Lithoupoli, an area in the working-class and densely populated Western Districts of Athens. Lithoupoli has some 80000 residents, many of whom have been stricken by the crisis, which has given rise to high levels of unemployment, particularly among young people. Some of the unemployed and homeless youth have taken over a building near the Botanic Gardens, turning it not merely into a shelter but also a social centre (known as the Botanic Squat), which is associated with a promising grassroots social movement.

These young people have come together in an informal group, under the name RAME, ${ }^{3}$ which organises the distribution of food. The public park near the Botanic Squat in Lithoupoli becomes the site for this distribution every second Sunday. People from all parts of Lithoupoli come up the hill to the abandoned but spacious park to purchase food. They buy directly from farmers who have come from their farms in the countryside, bringing produce of many different kinds to the park. The farmers use their own transport to do so, and pay their own fuel costs. They set up stalls, make up orders, and dispense change from makeshift tills, all with assistance from RAME activists, who argue that their market provides a winwin situation for sellers and buyers. It cuts out the chain of middlemen who would ordinarily buy at lower prices than the farmers can get in the park and sell at higher prices than the customers in the park have to pay. The RAME activists recruit selected farmers to sell produce in the park. They also try to ensure that they and their customers share a convivial experience on market days. Towards the end of each market day the activists slip away to their headquarters in Botanic Squat, reappearing with bottles of moonshine and plastic glasses, which they employ to encourage market participants to linger, relax and make conversation until well into the evening.

RAME comprised 35 people at the start of 2013. Some are unemployed youth - male and female - living in the squat, while others reside elsewhere in Lithoupoli. Some in the second category still have formal jobs. Many of them are older than those in the squat, and have histories of long-term involvement in left-wing politics, typically through association with parties such as left-wing SYRIZA. But the group as a whole is keen to escape the confines of institutionalised politics. The view is growing among RAME activists that even the left-wing parties in parliament may turn out to be part of the problem rather than the solution.

Such views are articulated by RAME activists and members of the public during the sessions that extend the produce markets into convivial Sunday evenings in the park. Discussion at these gatherings, or in meetings held at the Botanic Squat headquarters, is often animated, reflecting a general Greek political culture characterised by strong rhetoric and heated debate. People take turns to share their thoughts with others in attendance. Many give accounts of how their wages and pensions have been slashed in recent years, and how, in consequence, their ability to purchase sufficient food for the members of their households has declined sharply. They criticise both the government and parliament, often taking the view that parliamentarians of all parties have forgotten that they are meant to represent the interests of the people who voted for them.

Although a few of the participants in the discussions in the

2. PIIGS is the derogatory acronym for Portugal, Italy, Ireland, Greece and Spain. The public discourse around these - mainly Southern EU countries includes accusations of recklessness, inefficiency and corruption, largely associated with a huge public sector that needs to be cut back through fierce austerity measures. Greece is the only country, however, for which the possibility of exit from the Eurozone (the infamous 'grexit') has been seriously envisaged.

3. RAME is a fictitious acronym. The real Greek acronym is a word that means 'to break'. The original full name of the organisation can be translated as 'breaking the middleman'. 
park have university degrees, most who attend these sessions are of humble educational and socio-economic backgrounds. Yet they are listened to attentively as they recount their own present difficulties and seek to draw out the implications of their circumstances for RAME's future choices and moves. The audience often pays them the compliment of subjecting their opinions to fierce debate. The farmers selected to collaborate with RAME take relatively little part in these meetings themselves because many of them live and work far out of Athens, but the activists go to considerable lengths to relay the farmers' views about their own difficulties to the people who do attend. They explain that many farmers struggle to make a living on account of the low prices they receive for their produce from middlemen such as the food wholesalers and the retail chains. "You have to pay high prices, but they get low prices," argued a young activist at one of these gatherings. "What's the common thing in this equation?" he asked, and went on to provide his own answer. "It's the fat cut taken by the middlemen. Producers aren't necessarily the enemies of consumers, and both sides have to come together in a spirit of solidarity. We can help each other by coming together."

Participants in these discussions do not all have a history of left-wing activism. Judging from the hesitant way they spoke, I was convinced that many had either not been politically active up to that point or had hitherto supported moderate solutions to political issues. Such people often had less to say than the left-wingers, partly because they lacked easy command of the required vocabulary. But the way the austerity measures imposed on Greeks impinge on their everyday lives stimulates them to learn more about the anti-middleman movement and the ideas animating those involved in it. "Some of the things these youngsters say are quite new to me," an elderly lady, carrying a small bag of fruit she had just purchased, told me after we had stood side-by-side listening to a short public declaration by an activist in the middle of the market. "I've shopped at [the local branch of a supermarket chain] for so many years, and I never dreamt they were cheating me. But really, there has to be some explanation of the way things are now. My pension's gone down, but the [supermarket's] prices keep going up. Maybe they really don't care about people like me."

\section{From food distribution to wider aims}

My rough counts suggest that RAME drew the best part of a thousand customers to each of the market days I attended during the period of my fieldwork, which covered the last three months of 2012 and the first three of 2013. If one assumes that each customer represented a different household, it would follow that the movement's market supplied at least some of the food requirements of between five and ten per cent of Lithoupoli's residents over this period. Although this is good going for an experiment with a short history, RAME activists are keen to increase their reach in the area.

At the same time, their aim extends well beyond organising a self-help association to distribute food in a poor Athens neighbourhood. One activist, Voula, a middle-aged teacher who joined the movement out of political conviction born of her long association with SYRIZA as well as practical need, expressed the matter well. Over a cup of coffee at RAME's headquarters, she told me, "We are aspiring to shift the way in which people think about the economy overall. This is the real reason we engage in 'making economy on the street'." "Ultimately," she went on, in a didactic tone that suggested that I was a student in one of her classes, "the market we organise should help people arrive at a new understanding of what the crisis facing Greece is actually about." Her view was that the 'troika' institutions extending the emergency loans to the Greek government, the politicians accepting these loans, and the economists advising them to do so were providing only part of the truth about the crisis. Many states had built up large sovereign debts, she pointed out, but only some were being obliged to repay them within strict time frames. Moreover, the overwhelming focus on the nation's debt and the absolute need to repay it diverted attention from other dimensions of the crisis in the Greek economy, such as the existence of a whole layer of what she called 'parasites' located between producers and consumers of goods and services. These middlemen, she said, rack up the final prices of goods and services to an extent that is out of all proportion to the costs they incur in bringing producers and consumers together. The middlemen act without regard to the interests of producers or consumers and without sensitivity to the parlous state of the Greek economy. Producers such as farmers were struggling with falling demand for their produce, and consumers with their diminishing ability to purchase it. But, Voula insisted, the middlemen remained relentless in their efforts to maintain the absolute level of the cut they took for themselves in return for their largely unproductive and certainly overvalued service.

The above was in many respects a novel argument for many of Lithopouli's residents who made use of the middleman-less market in the public park. They were attracted by the prices charged in the market, which were considerably lower than those in nearby supermarkets and other retail outlets, but they did not understand fully why there were such price differences. As a key aspect of their mission, RAME activists sought to provide the people searching for cheaper food in their market with the information deemed necessary to make sense of their predicament. In addition to helping the farmers set up and tend their stalls, the activists also distributed leaflets to customers and passers-by pointing out the part RAME attributed to middlemen. Indeed, the activists organised into teams to facilitate the two aspects of their activity - what they called a 'production' team to assist with practical matters and a 'propaganda' team which took on the task of educating the public.

At various points during market days, members of the propaganda team would broadcast RAME 'communiques' to the people visiting the stalls. They would climb onto the back of a farmer's truck and, using a megaphone, make short, fiveminute speeches, not about the food items for sale but about how too much money was going into the pockets of middlemen under the present economic dispensation. They also argued that the solution to this lay in ordinary people in Greece standing together - as their audience was doing - in a show of solidarity between producers and consumers. RAME's aim, they said, was to develop this show of solidarity, by organising it into a long-term relationship between selected producers and the consumers of Lithopouli, in which 
each side would move beyond the condition of being anonymous market participants, and come to appreciate the difficulties facing the other.

The message of all the speeches I heard during market days was that the Botanic Squat market, where producers and consumers interacted face-to-face, was the first step towards an alternative way of organising everyday economic life. Those participating in the market were already engaged in building this alternative, but much more needed to be done to expand it. Why, the speakers asked, should this alternative not be developed more fully in the Botanic Squat market, and then extended to other areas of economic life? 'Initiatives like this one aim to counteract the pain our country and the people in it are undergoing,' concluded the RAME speaker on one occasion, drawing an enthusiastic round of applause from the hundred or so people within earshot.

After-market discussions over coffee and alcoholic drinks afforded more time for these issues to be discussed in depth. By staying on for these discussions, open to anyone who wished to participate, I learnt that the members of RAME intended to turn their movement - at present an informal grouping of activists - into a registered co-operative in the near future, drawing the producers and consumers they have brought into contact in the park into a formal body. This formal body would work through a market mechanism underpinned by internal solidarity, in which producers and consumers came to know each other personally and were concerned about each others' well-being, rather than the anonymous pursuit of individual gain.

RAME activists told me that their intention to set up a cooperative preceded, but was certainly given a fillip by, a meeting of anti-middleman groupings from across Greece held in 2012 in the town of Pieria, some 400 kilometres from Athens. Several RAME people made the journey to attend this meeting, and returned enthused by the fact that there were others in different parts of the country with a similar vision. One of the RAME delegates, Kostas, an out-of-work architect with long involvement in left-wing politics, told me that as a result of the gathering he now felt positive that 'the plan was going somewhere'. All the groups in attendance agreed that each needed to move swiftly to establish itself in the form of a co-operative and that they should all come together in a nationwide umbrella organisation of anti-middleman groups. Another RAME delegate, Anna, who is unemployed and in her early thirties, explained that "the sharing and distributing practices and ideas of solidarity are contagious. And they could build up to broader change. Bringing localised solidarity economies into contact could easily lead to a general contest against mainstream economics."

Acting both on their own and together with others of like mind, RAME activists have made a start to developing a vision of an economic system alternative to the one currently dominant in Greece. As two anthropologists looking into dissent movements in Greece point out, "Local peripheral actors imagine themselves as part of a larger, international community of discontent" (Theodossopoulos and Kirtsoglou 2010:119). At after-market meetings and in their own headquarters, they argued that a large part of the Greek economy could, in fact, be taken over by a network of co-operatives, linked together in horizontal rather than vertical fashion. By 2013 they had put together a leaflet, intended for distribution at their market in the park, which spelt out more of the principles that they and others in the general anti-middleman movement believed were essential to realising this vision.

One principle they articulated was that the anti-middleman movement should distance itself from any notion that it was motivated simply by goodwill and charity, which would open the door to the perception that some of the people involved were permanent givers and others permanent takers. "Farmers who join our co-operative should be able to make a better living than they are currently making", Kostas explained to me, "and the customers in the co-operative should get a better deal than they are getting. Neither will be asked to make a one-sided sacrifice for the sake of others."

One reason for this insistence was the RAME activists' conviction that some of their number should be able to secure paid employment in the proposed co-operative. If the co-operative was to contribute to securing the livelihoods of producers and consumers in hard times, it should also help to secure the livelihoods of those engaged in its co-ordination. This stipulation was, of course, a reflection of the dire employment situation in Greece and the fact that part of RAME's core consisted of young people who were unemployed. But these people were adamant that they would not turn into a new category of middlemen, because, they insisted, the structures within which they would work were to be animated by the ideal of solidarity in place of the baser principles of competition and individualised gain so prominent in the present economic dispensation. "The secret," said Kostas, "lies in bringing producers and consumers face-toface. If they can see each other as people struggling to make a living, each in their own way, we believe they will learn to moderate the demands they make. The problem is not simply that middlemen are greedy. When they talk to producers, they hide the fact that consumers are real people. When they talk to consumers, they hide the fact that producers are real people."

Another aspect of RAME's idealism deserves mention. This is namely that the farmers invited to bring their produce for direct distribution in the market are those who are willing to sign a pledge that they are not involved in far-right politics or hostile to migrants from other parts of the world who find themselves in Greece. They must attest, in particular, that they have no objection to employing these migrants as farm workers if the occasion arises. One point of the pledge is to distinguish the activities of RAME and similar groupings from those of the neo-Nazi Golden Dawn party, which has organised food distributions to poor people in the recent past, but has restricted the beneficiaries to Greek citizens and refused to give to foreigners. Another point returns to the issue of avoiding charity mentioned above. RAME activists told me that Golden Dawn gave the food it distributed away free, thereby positioning itself as a patron of indigent Greek citizens. Such actions, the activists said, take entirely the wrong route out of the impersonal market. RAME is prepared to go a long way to avoid any hint of a racist politics of patronage, which, the activists argued, has no place in the Greece those actively involved in the group wish to see. 


\section{Towards a human economy: co-operativism as change}

I am sympathetic to the goals of RAME activists. It is particularly interesting that they do not reject the market in toto. RAME activists have made it clear to me in many discussions that their goal is not to institute anything approaching a command economy in Greece. They said that the $20^{\text {th }}$ century had witnessed many experiments with centralised control over production and distribution, which had failed to deliver an economy in which decent people could live decent lives. Their ostensible ideals notwithstanding, most socialist states were organised in practice according to a hierarchical principle which promoted the interests of an elite at the expense of the population at large. Like the free-market system, which is currently causing such chaos in Greece, command economies have proved unable to manage the tension between human freedom and equality.

RAME activists therefore stand, they say, for an economy in which there is a reciprocal relationship between co-operatives and markets. Their idea is that markets will make cooperatives sustainable in the long run, provided they are embedded in structures which foster solidarity between people. One of these structures would be a state which provided the legal framework to support an economy consisting, in large part, of a network of linked co-operatives. State socialism attempted, in a sense, to turn the whole national economy into a single, all encompassing co-operative, but this inevitably removed the running of this entity a long way from the people it was supposed to serve. Far better, my informants suggested, is for one to think in terms of a series of localised co-operatives, autonomous and close to the people involved in them, but linked together by the fact of mutual concern and stabilised by state law tilted not in the direction of absolute property rights and private freedoms, but rather towards recognition of the human propensity for solidarity.

There is an awareness within RAME's ranks that the history of the co-operative movement, particularly in $20^{\text {th }}$ century Europe, has often left much to be desired. "Their history tells us," observed Voula, again in characteristic didactic mode, "that they have often been co-opted to the system of corporate capitalism, and for this reason came to be part of the problem. But this should not make us suspicious of the co-operative idea in its entirety."

This is about as far as the activists in RAME have gone to date in spelling out their vision of a new future for the Greek economy in their leaflets and communiqués and in their discussions with the public and with me. I do not think that they go further behind closed doors, and this is perhaps to be expected. The recent crisis of the neo-liberal economy may have encouraged co-operative movements to be more forthcoming than usual about their vision (Macpherson 2008), but one needs to bear in mind that the co-operative movement's politics are born not of ideologues but of practitioners (Whyte 1999). Ethnographies of agrarian co-operatives in different parts of the world have often pointed this out (e.g. Vargas-Cetina 2005). Like their fellows elsewhere, RAME activists trust that the full details of their vision of the future will emerge through their practical activities to sustain and expand the Botanic Squat market, set up a co-operative, and forge links with other co-operatives elsewhere in Greece.
Practice and planning go hand in hand, and it would be alien to their approach to draw up a comprehensive blueprint before implementation could begin.

There is much to be said for this 'practitioner's approach', but it can also be a weakness. One weakness I noticed in discussions with most of the activists associated with RAME is that their wholehearted involvement in the practical details of their particular market encouraged them to think that what they were doing was entirely without precedent. In one sense this is of course true - as far as I know, no one has ever set up a market without middlemen in the park near the Botanic Squat in Lithoupoli before. But this determined 'present-ism' has its drawbacks, especially in relation to the question with which I started this account. Journalists reporting on initiatives such as the Lithoupoli market tend to represent them as single-issue endeavours involving no more than the distribution of food to poor people. I suspect that part of the reason for this is that even if the journalists pay any attention to the larger vision behind the visible activities, they cannot see what authority those who articulate it have for doing so. Since people such as Voula are not always available to answer questions, why should the journalists give much weight to the views of a small number of unemployed young people living in a derelict squat, particularly if the latter claim that they are inventing an entirely new wheel by setting it in motion? The economists have huge authority behind their pronouncements about the nature of the current Greek crisis and their solutions to it. Meanwhile the squatters in Lithoupoli have little or no backing for their counterview that the crisis is as much about the depredations of middlemen as it is about sovereign debt, and that building a co-operative movement is just as important as paying the debt at any cost. Journalists can easily dismiss this argument as a utopian fantasy put forward by wide-eyed youth.

But the issues the RAME activists are exploring have been explored before, and whether they know it or not, their ideas are rooted in an important intellectual history which could be deployed to lend authority to their vision. It is beyond this article's scope to give a detailed account of the ideas that scholars such as Mauss and Polanyi put forward about the importance of co-operative movements and solidarity economies, but it does bear pointing out that they grappled, with considerable sophistication, with many of the questions which confront the activists in RAME and their fellows throughout Greece at present. Mauss and Polanyi were highly critical of the 'free market' (or 'market society') and its adverse social repercussions (Bura 2007), but were also wary of abolishing the market and handing over its task of allocating goods and services to the bureaucracy. They held that markets and bureaucracies were inescapable features of an era of industrial complexity, but insisted that the ways in which they worked had to be tempered to the interests of human beings, whose material and social well-being should be society's chief end. Both advocated the co-operative movement as the principal means to achieve this, and gave considerable thought to the ways in which markets, states and co-operatives could be brought together to attain the goal which Mauss called 'practical socialism'.

In recent times there has been a serious effort to remind academics of the importance of the work of Mauss and 
Polanyi (Sigaud 2002, Hann 2007, 20I I). But this effort can also be extended in other ways. There is little doubt in my mind that many of the RAME activists would also benefit from knowing about this work, because its connections with their endeavours are so close. In saying this I do not mean to imply that they are in need of a short course on 'Mauss and Polanyi for beginners' to fill the gaps in their knowledge of how to launch a co-operative movement. Such a move would be indefensibly condescending towards them, as well as entirely out of keeping with Mauss' own understanding that the practices involved in fashioning co-operatives were the key to the emergence of practical socialism. When he told the First National and International Congress of Socialist Co-operatives in 1900 that "we will educate [the citizen] for his revolutionary task by giving him a foretaste of all the advantages that the future society will be able to offer him", he was not announcing his intention to write a text book. On the contrary, he argued that, "we will [educate the citizen] by creating a veritable arsenal of socialist capital in the midst of bourgeois capital".

However, there is scope for assisting the anti-middleman activists to achieve the confidence to be derived from knowing that their current efforts were preceded by a distinguished pedigree, and that not all past attempts to establish a practical socialism were simply co-opted by corporate capital. Mauss and Polanyi were big enough guns to challenge the authority on which the economists call to back their version of the economic crisis, and it seems important to begin to brandish them if the activists are to get the fair hearing from the media their efforts deserve.

Anthropologists are often content merely to record what the subjects of their research are doing and saying. Given my sympathy with the aims of the people with whom I am working, I should like to go further than this. But the challenge remains to figure out a way to do this which does not involve any unwarranted claim that one has special knowledge or insight which they lack. In the case of my research in Lithoupoli it is easy for me to acknowledge that I have infinitely less experience than they do in running an anti-middleman market and planning to establish a co-operative. They give me an important practical lesson in creating an economy attuned to human beings, and this lesson adds considerable significance to my participation in a research project under the title 'The Human Economy'. Perhaps, starting on my next field research trip to Athens, I can find a way to make the fact that I have studied Mauss and Polanyi carefully of some use to them.

\section{References}

Bugra, Ayse. 2007. 'Introduction', in Reading Karl Polanyi for the twenty-first century: market economy as a political project. Edited by A. Bura and K. Agartan. New York: Palgrave Macmillan.

Hann, Chris. 2007. A new double movement? Anthropological perspectives on property in the age of neoliberalism. SocioEconomic Review 5: 287-318

Hann, Chris. 20I I. 'Embedded socialism? Land, labour and money in eastern Xinjiang', in Market and society: the great transformation today. Edited by C. Hann and K. Hart. Cambridge: Cambridge University Press.

Herzfeld, Michael. 20II. Crisis attack: impromptu ethnography in the Greek maelstrom. Anthropology Today 27: 5.

Macpherson, lan. 2008. The co-operative movement and the social economy traditions: reflections on the mingling of broad visions. Annals of Public and Cooperative Economics 79 (3-4): 625-42.

Sigaud, Lygia. 2002. The vicissitudes of The Gift. Social Anthropology 10 (3): 335-58.

Sitrin, Marina. 2012. Everyday revolutions: horizontalism and autonomy in Argentina. London: Zed Books.

Stuckler, David; Sanjay Basu. 2013. The body economic: why austerity kills. New York: Basic Books.

Theodossopoulos, Dimitrios. 2013. Infuriated with the infuriated? Blaming tactics and discontent about the Greek financial crisis. Current Anthropology 54 (2): 200-21.

Theodossopoulos, Dimitrios; Elisabeth Kirtsoglou. 2010. 'Introduction', in United in discontent: local responses to cosmopolitanism and globalisation. Edited by D. Theodossopoulos and E. Kirtsoglu. Oxford: Berghahn.

Varoufakis, Yanis. 20II. The global minotaur: America, the true origins of the financial crisis and the future of the world economy. London: Zed Books.

Vargas-Cetina, Gabriela. 2005. From the community paradigm to the ephemeral association in Chiapas, Mexico. Critique of Anthropology 25 (3): 229-5I.

Whyte, William F. 1999. The Mondragón Cooperatives in 1976 and 1998. Industrial and Labor Relations Review 52 (3): 478-8I. 